\title{
Hematological and biochemical reference values for C57BL/6, Swiss Webster and BALB/c mice
}

\section{Valores de referência hematológicos e bioquímicos para camundongos das linhagens C57BL/6, Swiss Webster e BALB/c}

\author{
Ed Wilson SANTOS ${ }^{1}$; Dalila Cunha de OLIVEIRA ${ }^{1}$; Araceli HASTREITER ${ }^{1}$; Graziela Batista da SILVA ${ }^{1}$; \\ Jackeline Soares de Oliveira BELTRAN ${ }^{1}$; Maristela TSUJITA ${ }^{1}$; Amanda Rabelo CRISMA ${ }^{1}$; Silvânia Meiry \\ Peris NEVES ${ }^{2}$; Ricardo Ambrósio FOCK ${ }^{1}$; Primavera BORELLI ${ }^{1}$
}

\footnotetext{
${ }^{1}$ Universidade de São Paulo, Faculdade de Ciências Farmacêuticas, Departamento de Análises Clínicas e Toxicológicas, Laboratório de Hematologia Experimental, São Paulo - SP, Brasil

${ }^{2}$ Biotério de Produção e Experimentação da Faculdade de Ciências Farmacêuticas e do Instituto de Química da Universidade de São Paulo, São Paulo - SP, Brasil
}

\begin{abstract}
The use of animals in scientific research has contributed significantly to the development of science, promoting various advances in understanding the metabolic machinery and the discovery of treatments and preventive measures applied to human and veterinary medicine. The development and use of alternative methods is encouraged; however, in some situations, the use of animals in accordance with ethical policies is still required. Established hematological and clinical chemistry reference values in laboratory animals are essential to evaluate functional changes; however, there are few data in the literature on these values, being fundamentally a comparative basis. The aim of this investigation was the establishment of hematological and clinical chemistry reference values in common strains/stocks of mice used in animal experimentation. Blood profile (hemogram, reticulocytes and myelogram) and clinical chemistry serum determination of total protein, albumin, glucose, cholesterol, triglycerides, calcium and phosphorus were evaluated using C57BL/6, BALB/c and Swiss Webster mice, male, 2-3 months old. The results standardize reference intervals in animals reared in Laboratory Animal Facility, reflecting the expected condition in rodents subjected to scientific research.
\end{abstract}

Keywords: Hematology. Reference values. Mice.

\begin{abstract}
Resumo
O uso de animais na pesquisa científica tem contribuído significativamente para o desenvolvimento da ciência, promovendo vários avanços na compreensão da maquinaria metabólica, bem como a descoberta de tratamentos e medidas preventivas aplicadas à medicina humana e veterinária. O desenvolvimento e utilização de métodos alternativos é encorajado, no entanto, em algumas situações, ainda é necessária a utilização de animais em conformidade com termos éticos. Estabelecer valores de referência hematológicos e bioquímicos para animais de laboratório é essencial para avaliar alterações funcionais, no entanto, existem poucos dados na literatura sobre estes valores, sendo fundamentalmente uma base comparativa. O presente trabalho foi delineado para estabelecer valores de referência hematológicos e bioquímicos em linhagens camundongos utilizados em pesquisa científica. Foram avaliados o perfil sanguíneo (hemograma, reticulócitos e mielograma) e a determinação bioquímica sérica de proteínas totais, albumina, glicose, colesterol, triglicerídeos, cálcio e fósforo. Foram utilizados camundongos C57BL/6, $\mathrm{BALB} / \mathrm{c}$ e Swiss Webster, do sexo masculino, 2-3 meses de idade. Os resultados padronizam intervalos de referência em camundongos criados em Biotério, refletindo a condição esperada nesses animais submetidos à investigação científica.
\end{abstract}

Palavras-chave: Hematologia. Valores de referência. Camundongos. 
Correspondence to:

Primavera Borelli

Experimental Hematology Laboratory, Department of Clinical e Toxicological Analyses, Faculty of Pharmaceutical Sciences, University of Sao Paulo.

Avenida Lineu Prestes, 580 - Bloco 17

CEP 05508-900, São Paulo, SP, Brazil

E-mail: borelli@usp.br

Received: 14/09/2015

Approved: 06/04/2016

\section{Introduction}

The use of animals in scientific research has generated controversy. However, it has significantly contributed to the development of science, promoting several advances in understanding the metabolic machinery as well as the discovery of treatments and preventive measures applied to both human and veterinary medicine. Technological refinements in the generation of experimental models have led to a reduction in the number of animals per experimental group, principally due to reducing the variability observed in each experiment (RESTEL et al., 2014). Despite efforts to develop and use alternative methods, in some situations, the use of animals in accordance with ethical terms is still needed. Several animal species have been used, with mice the most heavily used because they are easy to treat, breed quickly, have a short life, a low cost of management and have a physiological similarity to the human cycle (FOSTER et al., 1982).

The similarities between the genomes of human and mouse model are the foundation of much of modern biology, with model organism experimentation permitting valuable insights into biological function and the etiology of human disease (EMES et al., 2003).

Therefore, it is important to know the normal ranges for many hematological and biochemical parameters of homeostasis assessment because pathological processes can influence at the metabolism and alter the results obtained in experimental procedures.
The reference values for biochemical and hematological parameters are often sought to play up the metabolic status of the animals used in research. These values may vary according to the animal facility of origin, laboratories, age, sex, management conditions, diet and techniques used. So it is important to strive to generate a historical database benchmark based on the methods used. Published reference values can provide an investigator a useful tool to begin data evaluation, especially if the laboratory does not have enough historical data of rodents (SERFILIPPI et al., 2003).

Currently, there are few data that can be use in scientific research as reference values for mice from animal facilities. The aim of this study is to establish reference values for hematological parameters for two inbred mice strains $(\mathrm{C} 57 \mathrm{BL} / 6$ and $\mathrm{BALB} / \mathrm{c})$ and one outbred mouse strain (Swiss Webster).

\section{Material and Methods}

\section{Animals and diets}

Specified-pathogen-free C57BL/6 $(\mathrm{n}=49), \mathrm{BALB} / \mathrm{c}$ $(\mathrm{n}=42)$ and Swiss Webster $(\mathrm{n}=40)$ mice, $2-3$ months old, male, were obtained and maintained in the Animal Production and Experimentation of the Faculty of Pharmaceutical Sciences and Institute of Chemistry, University of São Paulo. The animals were reared in cages made of polypropylene, measuring $30 \mathrm{~cm}$ x 20 $\mathrm{cm} \times 13 \mathrm{~cm}$, with wireframe grade stainless steel feeder and fitting for the water cooler. Five animals were placed per cage. Each cage was changed twice a week. Adaptation was carried out for 10 to 14 days under the same conditions of environmental temperature (22$\left.25^{\circ} \mathrm{C}\right)$ and a relative humidity $(55 \pm 10 \%)$, with light/dark cycle of $12 / 12$ hours. The diet was prepared in the laboratory, according to the recommendations of the American Institute of Nutrition for adult mice (AIN- 93M) (REEVES et al., 1993). The diet prepared contained $100 \mathrm{~g} / \mathrm{kg}$ sucrose, $80 \mathrm{~g} / \mathrm{kg}$ corn oil, $10 \mathrm{~g} / \mathrm{kg}$ fiber, $2.5 \mathrm{~g} / \mathrm{kg}$ choline bitartrate, $1.5 \mathrm{~g} / \mathrm{kg} \mathrm{L-}$ methionine, $40 \mathrm{~g} / \mathrm{kg}$ mineral mixture, $10 \mathrm{~g} / \mathrm{kg}$ vitamin mixture, $120 \mathrm{~g} / \mathrm{kg}$ casein and $636 \mathrm{~g} / \mathrm{kg}$ cornstarch. 
Breeding pairs received commercial food (Nuvilab $\left.\mathrm{CR} 1^{\circ}\right)$.

The animals were used in experiments approved by the Ethics Committee of the Faculty of Pharmaceutical Sciences, University of São Paulo, by protocols: CEUA/FCF/282 (C57BL/6), CEUA/FCF/316 $(\mathrm{BALB} / \mathrm{c})$ and $\mathrm{CEUA} / \mathrm{FCF} / 366$ (Swiss Webster). Breeding pairs of all strains were obtained from the Taconic Biosciences ${ }^{\oplus}$, Germantown, NY, USA in 2001.

\section{Blood samples}

Whole blood samples were obtained by puncture of the axillary plexus of mice anesthetized with xylazine $(16 \mathrm{mg} / \mathrm{kg})$ and ketamine $(120 \mathrm{mg} / \mathrm{kg})$. Samples were collected using potassium salt of ethylene dimetilenotetracetic acid (EDTA) $10 \%$ as anticoagulant, in the proportion of $50 \mu \mathrm{l}$ for each 1.0 $\mathrm{mL}$ of blood, and used for the complete blood count. Blood samples collected without anticoagulant were used to obtain the serum separated by centrifugation $\left(1,500 \mathrm{rpm}\right.$ for 10 minutes at $\left.4^{\circ} \mathrm{C}\right)$ and frozen in aliquots at $-40^{\circ} \mathrm{C}$. Serum samples were used for determination of total cholesterol, triglycerides, calcium, phosphate, albumin and total protein. The glucose measurement was performed in blood samples collected from the tail of anesthetized animals (8 to 10 hour of fasting).

\section{Complete blood count (CBC)}

Whole blood was used for determination of hemoglobin, hematocrit, red blood cells (RBC) and white blood cells (WBC) count. The analyses were performed on automatic blood cell analyzer $\mathrm{ABC}$ Vet (HORIBA $\left.{ }^{\circ}, \mathrm{UK}\right)$. Using the relationship between hematocrit, hemoglobin and erythrocyte count, it was possible to calculate the $\mathrm{RBC}$ indices: mean corpuscular volume (MCV), mean corpuscular hemoglobin $(\mathrm{MCH})$ and mean corpuscular hemoglobin concentration (MCHC). The differential leukocyte counts were performed on blood smears prepared immediately after sample collection and stained with May-Grunwald-Giemsa method, modified (ROSENFELD, 1947). The slides were analyzed by light microscopy and at least 100 leukocytes were counted. The reticulocyte count was performed by brilliant cresyl blue method (DACIE; LEWIS, 1985).

\section{Myelogram}

Animals were euthanized and had both femurs and tibias collected. After cutting their epiphysis, bone marrow cells were obtained by flushing femoral and tibia cavity with $5 \mathrm{~mL}$ of culture medium McCoy's $5 \mathrm{~A}$ modified (SIGMA ${ }^{\circ}$, Chemical Company, St. Louis, MO). The obtained cell suspension was used to count the total number of nucleated cells in a Neubauer chamber (using Turk liquid as diluent) and for the slides preparation obtained by cytospin and stained with May-Grunwald-Giemsa method modified (ROSENFELD, 1947). The slides were examined by light microscopy and at least 500 cells/animal were evaluated in order to carry out identification and quantification of the cell populations.

\section{Biochemical measurements}

Serum samples of cholesterol, triglycerides, total protein, albumin, calcium and phosphorus were quantified using respective kits (Labtest ${ }^{\oplus}$, Brazil) according to the manufacturer's instructions. The samples were processed in duplicate and analysed in Varioskan Flash ${ }^{\odot}$. Glucose was determined using an Accu-Check Advantage glucometer (Roche $\left.{ }^{\circledast}\right)$. The animals were not fasted.

\section{Results}

The results are presented in the tables below separated by strains/stock. They are expressed in Range (minimum and maximum values) and Mean \pm SD (mean and standard deviation). The results are shown in table 1, being considered as a reference for hematologic evaluation from Laboratory Animal Facility rodents used in experimental procedures. 
Table 1 - Hematological values in male Swiss Webster, C57BL/6 and BALB/c mice in Sao Paulo, Brazil - 2016

\begin{tabular}{|c|c|c|c|c|}
\hline & & $\begin{array}{l}\text { Swiss Webster } \\
(n=40)\end{array}$ & $\begin{array}{l}\text { C57BL/6 } \\
(n=49)\end{array}$ & $\begin{array}{l}\text { BALB/c } \\
(n=42)\end{array}$ \\
\hline \multirow{2}{*}{$\begin{array}{l}\text { Hemoglobin } \\
\text { (g/dL) }\end{array}$} & Range & $11.1-14.8$ & $11.2-16.4$ & $11.6-15.8$ \\
\hline & Mean \pm SD & $12.1 \pm 1.3$ & $12.9 \pm 1.4$ & $13.4 \pm 1.4$ \\
\hline \multirow{2}{*}{ Hematocrit (\%) } & Range & $32.1-46.5$ & $33.5-47.8$ & $37.4-51.7$ \\
\hline & Mean \pm SD & $37.6 \pm 3.6$ & $39.6 \pm 3.9$ & $42.6 \pm 2.8$ \\
\hline \multirow{2}{*}{$\begin{array}{l}\text { Red blood cells } \\
\left(\times 10^{6} / \mathrm{mm}^{3}\right)\end{array}$} & Range & $5.2-10.4$ & $6.1-10.7$ & $7.1-9.5$ \\
\hline & Mean \pm SD & $8.1 \pm 1.0$ & $8.7 \pm 1.0$ & $8.9 \pm 0.9$ \\
\hline \multirow{2}{*}{$\operatorname{MCV}(\mathbf{f L})$} & Range & $44.2-58.5$ & $43.4-47.8$ & $41.5-57.4$ \\
\hline & Mean \pm SD & $46.7 \pm 2.0$ & $45.3 \pm 1.8$ & $47.9 \pm 3.6$ \\
\hline \multirow{2}{*}{ MCH (pg) } & Range & $14.0-18.7$ & $14.8-17.6$ & $14.1-18.4$ \\
\hline & Mean \pm SD & $15.1 \pm 1.1$ & $14.9 \pm 0.9$ & $15.1 \pm 1.0$ \\
\hline \multirow{2}{*}{ MCHC (\%) } & Range & $28.4-38.5$ & $29.3-35.9$ & $30.5-34.2$ \\
\hline & Mean \pm SD & $32.3 \pm 2.7$ & $32.5 \pm 1.3$ & $31.8 \pm 2.5$ \\
\hline \multirow{2}{*}{ Reticulocytes (\%) } & Range & $3.1-5.4$ & $3.8-4.2$ & $3.0-5.8$ \\
\hline & Mean \pm SD & $3.5 \pm 0.2$ & $6.7 \pm 0.4$ & $3.8 \pm 0.2$ \\
\hline \multirow{2}{*}{$\begin{array}{l}\text { Leukocytes } \\
\left(\times 10^{3} / \mathrm{mm}^{3}\right)\end{array}$} & Range & $1.9-7.0$ & $1.8-5.2$ & $1.5-4.8$ \\
\hline & Mean \pm SD & $2.5 \pm 1.4$ & $2.2 \pm 0.9$ & $2.6 \pm 0.9$ \\
\hline \multirow{2}{*}{ Platelets $\left(\times 10^{3} / \mathrm{mm}^{3}\right)$} & Range & $315-758$ & $285-890$ & $325-888$ \\
\hline & Mean \pm SD & $607 \pm 116$ & $627 \pm 146$ & $602 \pm 121$ \\
\hline
\end{tabular}

SD: standard deviation

Differential leukocyte count consisted of evaluation of total and relative leukocytes number of different leukocyte populations (segmented neutrophils, lymphocytes, eosinophils, monocytes and basophils). The results are shown in table 2 and present small variations between individual strains/stock.
Interestingly the lymphocyte population is predominantly in peripheral blood, corresponding, at least, to $70 \%$ of total leukocytes. Unlike rodents, human beings have a larger number of segmented neutrophils compared to lymphocytes. It was not found basophils in $\mathrm{C} 57 \mathrm{Bl} / 6$.

Table 2 - Relative and total number of leukocytes and different leukocyte populations (segmented neutrophils, lymphocytes, eosinophils, monocytes and basophils) according to the kind of mice strain in Sao Paulo, Brazil $-2016$

\begin{tabular}{|c|c|c|c|c|c|c|c|}
\hline \multirow{2}{*}{\multicolumn{2}{|c|}{ Parameters }} & \multicolumn{2}{|c|}{$\begin{array}{c}\text { Swiss Webster } \\
(n=30)\end{array}$} & \multicolumn{2}{|c|}{$\begin{array}{c}\text { C57BL/6 } \\
(n=32)\end{array}$} & \multicolumn{2}{|c|}{$\begin{array}{l}\text { BALB/c } \\
(n=28)\end{array}$} \\
\hline & & $\left(/ \mathrm{mm}^{3}\right)$ & $\%$ & $\left(/ \mathrm{mm}^{3}\right)$ & $\%$ & $\left(/ \mathrm{mm}^{3}\right)$ & $\%$ \\
\hline $\begin{array}{l}\text { Segmented } \\
\text { neutrophils }\end{array}$ & $\begin{array}{c}\text { Range } \\
\text { Mean } \pm \text { SD }\end{array}$ & $\begin{array}{l}200-800 \\
341 \pm 151\end{array}$ & $\begin{array}{c}10-23 \\
13.7 \pm 4.5\end{array}$ & $\begin{array}{c}100-600 \\
335 \pm 46\end{array}$ & $\begin{array}{c}8-20 \\
12.0 \pm 1.1\end{array}$ & $\begin{array}{c}300-900 \\
625 \pm 87\end{array}$ & $\begin{array}{c}11-29 \\
21.6 \pm 1.7\end{array}$ \\
\hline Eosinophils & $\begin{array}{c}\text { Range } \\
\text { Mean } \pm \text { SD }\end{array}$ & $\begin{array}{c}0-80 \\
17.6 \pm 1.5\end{array}$ & $\begin{array}{c}0-3 \\
0.5 \pm 0.1\end{array}$ & $\begin{array}{c}0-40 \\
13.7 \pm 1.4\end{array}$ & $\begin{array}{c}0-3 \\
0.6 \pm 0.2\end{array}$ & $\begin{array}{c}0-80 \\
17.0 \pm 15.1\end{array}$ & $\begin{array}{c}0-5 \\
0.7 \pm 0.4\end{array}$ \\
\hline Basophils & $\begin{array}{c}\text { Range } \\
\text { Mean } \pm \text { SD }\end{array}$ & $\begin{array}{c}0-40 \\
5.2 \pm 3.7\end{array}$ & $\begin{array}{c}0-1 \\
0.2 \pm 0.1\end{array}$ & $\begin{array}{l}0 \\
0\end{array}$ & $\begin{array}{l}0 \\
0\end{array}$ & $\begin{array}{c}0-60 \\
7.6 \pm 5.3\end{array}$ & $\begin{array}{c}0-1 \\
0.1 \pm 0.1\end{array}$ \\
\hline Lymphocytes & $\begin{array}{c}\text { Range } \\
\text { Mean } \pm \text { SD }\end{array}$ & $\begin{array}{c}1000- \\
3100 \\
2164 \pm 736\end{array}$ & $\begin{array}{c}74-90 \\
85.0 \pm 4.5\end{array}$ & $\begin{array}{c}1000- \\
3200 \\
2264 \pm 169\end{array}$ & $\begin{array}{c}76-91 \\
86.7 \pm 1.6\end{array}$ & $\begin{array}{l}900-3200 \\
2104 \pm 217\end{array}$ & $\begin{array}{c}65-87 \\
74.2 \pm 2.4\end{array}$ \\
\hline Monocytes & $\begin{array}{c}\text { Range } \\
\text { Mean } \pm \text { SD }\end{array}$ & $\begin{array}{c}0-80 \\
18.5 \pm 2.2\end{array}$ & $\begin{array}{c}0-5 \\
0.7 \pm 0.1\end{array}$ & $\begin{array}{c}0-80 \\
21.5 \pm 3.1\end{array}$ & $\begin{array}{c}0-4 \\
0.9 \pm 0.3\end{array}$ & $\begin{array}{c}0-200 \\
49.3 \pm 19.3\end{array}$ & $\begin{array}{c}0-6 \\
3.1 \pm 0.6\end{array}$ \\
\hline
\end{tabular}

SD: standard deviation 
Values of the mielogram in different strains/stock analyzed are showed in table 3. No significant differences were found in bone marrow cellularity among the three mice strains.

Table 3 - Results of different cell populations present in the bone marrow according to the kind of mice strain in Sao Paulo, Brazil - 2016

\begin{tabular}{|c|c|c|c|c|}
\hline Parameters $\left(\times 10^{6} \mathrm{~mm}^{3}\right)$ & & $\begin{array}{l}\text { Swiss Webster } \\
(n=28)\end{array}$ & $\begin{array}{l}\text { C57BL/6 } \\
(n=28)\end{array}$ & $\begin{array}{l}\text { BALB/c } \\
(n=28)\end{array}$ \\
\hline Total Cells & $\begin{array}{c}\text { Range } \\
\text { Mean } \pm \text { SD }\end{array}$ & $38.1 \pm 2.4$ & $21.5 \pm 2.7$ & $23.8 \pm 1.4$ \\
\hline Blasts & $\begin{array}{c}\text { Range } \\
\text { Mean } \pm S D\end{array}$ & $0.9 \pm 0.3$ & $0.6 \pm 0.1$ & $0.7 \pm 0.3$ \\
\hline Young Forms & $\begin{array}{c}\text { Range } \\
\text { Mean } \pm \text { SD }\end{array}$ & $1.2 \pm 0.4$ & $0.9 \pm 0.1$ & $0.5 \pm 0.1$ \\
\hline Ring Forms & $\begin{array}{c}\text { Range } \\
\text { Mean } \pm \text { SD }\end{array}$ & $1.1 \pm 0.5$ & $2.0 \pm 0.1$ & $0.9 \pm 0.2$ \\
\hline Segmented neutrophils & $\begin{array}{c}\text { Range } \\
\text { Mean } \pm S D\end{array}$ & $12.8 \pm 4.5$ & $23.4 \pm 0.6$ & $14.3 \pm 1.9$ \\
\hline Eosinophils & $\begin{array}{c}\text { Range } \\
\text { Mean } \pm S D\end{array}$ & $0.8 \pm 0.4$ & $0.4 \pm 0.1$ & $0.9 \pm 0.2$ \\
\hline Lymphocytes & $\begin{array}{c}\text { Range } \\
\text { Mean } \pm S D\end{array}$ & $4.0 \pm 1.2$ & $10.2 \pm 1.0$ & $4.8 \pm 0.9$ \\
\hline Monocytes / Macrophages & $\begin{array}{c}\text { Range } \\
\text { Mean } \pm \text { SD }\end{array}$ & $0.9 \pm 0.5$ & $0.5 \pm 0.1$ & $0.4 \pm 0.1$ \\
\hline Pro-erythroblasts and basophilic erythroblasts & $\begin{array}{c}\text { Range } \\
\text { Mean } \pm \text { SD }\end{array}$ & $1.0 \pm 0.4$ & $0.9 \pm 0.1$ & $1.3 \pm 0.3$ \\
\hline Polychromatophilic and orthochromatic erythroblasts & $\begin{array}{c}\text { Range } \\
\text { Mean } \pm \text { SD }\end{array}$ & $7.7 \pm 2.8$ & $7.4 \pm 1.5$ & $6.8 \pm 0.7$ \\
\hline Plasmocytes & $\begin{array}{c}\text { Range } \\
\text { Mean } \pm \text { SD }\end{array}$ & $0.2 \pm 0.1$ & $0.1 \pm 0,1$ & $0.2 \pm 0.1$ \\
\hline Megakaryocytic lineage & $\begin{array}{c}\text { Range } \\
\text { Mean } \pm S D\end{array}$ & $0.5 \pm 0.2$ & $0,9 \pm 0,6$ & $0.3 \pm 0.1$ \\
\hline Granule / Erythroid ratio & $\begin{array}{c}\text { Range } \\
\text { Mean } \pm \text { SD }\end{array}$ & $3.2 \pm 0.4$ & $3.1 \pm 0.1$ & $2.9 \pm 1.6$ \\
\hline
\end{tabular}

SD: standard deviation

Table 4 shows the blood serum biochemical measurements performed (total protein, albumin, glucose, cholesterol, triglycerides, calcium and phosphorus). The concentrations of cholesterol and triglycerides showed no significant differences among mice strains.

Table 4 - Results of biochemical values of three male mice strains in Sao Paulo, Brazil 2016

\begin{tabular}{ccccc}
\hline Parameters & & $\begin{array}{c}\text { Swiss Webster } \\
(\mathbf{n}=\mathbf{4 0})\end{array}$ & $\begin{array}{c}\text { C57BL/6 } \\
(\mathbf{n}=\mathbf{4 9})\end{array}$ & $\begin{array}{c}\text { BALB/c } \\
\mathbf{( n = 4 2 )}\end{array}$ \\
& Range & $3.2-5.9$ & $4.4-5.8$ & $4.5-5.8$ \\
Total proteins (g/dL) & Mean \pm SD & $5.1 \pm 0.2$ & $5.3 \pm 0.4$ & $5.2 \pm 0.4$ \\
& Range & $2.5-3.4$ & $1.4-3.1$ & $1.3-3.2$ \\
Albumin (g/dL) & Mean \pm SD & $2.8 \pm 0.1$ & $2.5 \pm 0.3$ & $2.1 \pm 0.2$ \\
& Range & $130-210$ & $150-275$ & $75-128$ \\
Glucose (mg/dL) & Mean \pm SD & $158 \pm 4$ & $185 \pm 15$ & $112 \pm 15$ \\
& Range & $80-150$ & $80-100$ & $117-150$ \\
Cholesterol (mg/dL) & Mean \pm SD & $73 \pm 10$ & $89 \pm 9$ & $135 \pm 6$ \\
& Range & $70-150$ & $80-120$ & $62-155$ \\
Triglycerides (mg/dL) & Mean \pm SD & $130 \pm 7$ & $100 \pm 10$ & $106 \pm 13$ \\
& Range & $4.2-9.9$ & $5.7-10.3$ & $6.6-9.8$ \\
Calcium (mg/dL) & Mean \pm SD & $8.2 \pm 0.4$ & $7.6 \pm 0.3$ & $8.0 \pm 0.2$ \\
& Range & $5.2-10.8$ & $4.0-9.6$ & $5.1-10.2$ \\
Phosphorus (mg/dL) & Mean \pm SD & $6.7 \pm 0.5$ & $5.6 \pm 0.5$ & $6.7 \pm 1.4$ \\
\hline
\end{tabular}

SD: standard deviation 


\section{Discussion}

The task of establishing a range of reference values for rodents is very difficult, because many variables, such as gender, age, genetic variation, diet and environmental conditions in which these animals are submitted must be considered. The Institute for Clinical and Laboratory Standards suggests that values are defined by the result obtained with quantitative measurement of analytes based on the defined criteria (CLSI, 2000).

The nutritional status of laboratory animals influences their ability to achieve their genetic potential for growth, longevity, reproduction, as well as their response to pathogens and other types of environmental stress. A balanced diet of known and reproducible formulation ensures not only the welfare of animals, but also the quality of the experimental results. The reference diet for laboratory animals is the one from the American Institute of Nutrition (AIN93) (REEVES et al., 1993), which proposes a formulation for the stages of growth, pregnancy and lactation (AIN-93G) and a formulation for the maintenance phase of adult animals (AIN-93M). This type of specification was defined to standardize nutritional studies in rodents, reducing the inherent variation of the diet from cereals or natural ingredients and easing interpretation and comparison of results (NRC, 1995).

Mice rapidly develop during childhood. They reach sexual maturity at 40 to 60 days of age. In adulthood, every month of the animal is approximately equivalent to 2.5 human years (QUINN, 2005). Several authors performed experimental studies in rats and estimated 30 days of human life for everyday life of the animal (ANDREOLLO et al., 2012).

Environmental where rodents are may exert influences on their metabolism. This is reflected in the response observed in animal experiments. Therefore, it is essential to maintain stable environmental conditions to have greater confidence in the reproduction of the experimental results. The main factors that influence the environment are: temperature, relative humidity, ventilation, lighting, noise, handling, housing, food, water, pathogens and contact with other animals.

Since rodents are homeotermous, they are very sensitive to temperature changes. International standards recommend a variation between $20-22^{\circ} \mathrm{C}$. The relative humidity should be stable between $55 \pm$ $10 \%$ and air exchange (ventilation) must also be constant (15-20 exchanges / hour) to avoid disorders of the respiratory system as well as development of other diseases (ANDERSEN et al., 2004).

The lighting can affect the physiology, morphology and behavior of many animals; thus improper lighting is stressful. Three lighting factors must be evaluated: duration, intensity and wavelength. The period of exposure to light can affect the reproductive behavior of animals as well as their weight and food intake. To avoid lighting variations, timers are used in Laboratory Animal Facilities to control dark/light cycles. Generally Laboratory Animal Facilities use to 12/12 hours dark/light cycles (RIVERA, 2010).

Rodents can adapt to continuous environmental noise, but long duration noises, high intensity sharp noises or disrupt noises can cause stress, metabolic abnormalities, reduced fertility, cannibalism and hearing damage. Moreover, some ordinary sounds found in laboratories and animal facilities can stress the animals, like running water or pressure hoses. Overcrowded cages also generate higher levels of sound that can hamper communication between animals and cause stress (TEIXEIRA; FILHO, 2009).

The cages must have dimensions necessary for the development of the animal. Small or overcrowded cages can lead to stress, fights and disease. According to the National Research Council (NRC, 2011), dimensions measures for mice they should be between $77.4-96.7 \mathrm{~cm}^{2}$ floor by $32.35 \mathrm{~cm}$ of height. The cage should have materials that absorb moisture, such as sawdust and paper strips, in order to keep the place dry.

Hematological reference values of animals used in scientific research generally showed no distinction 
among lineages (FOSTER et al., 1982; MITRUKA; RAWNSLEY, 1997), which hinders the assessment of the status of experimental animals. Currently, studies that aim the establishment of reference hematological values have been published (BRANCO et al., 2011; RESTELL et al., 2014). The hematological and biochemical values generated from the rodents in our study are intended to provide guidance for normal values to different strains.

When it was compared the results obtained in this investigation with Jackson and Taconic Lab (JACKSON, 2007; TACONIC, 2016) data, as well as other national (ALMEIDA et al., 2008; BRANCO et al., 2011) and international (SERFILIPPI et al., 2003; RESTELL et al., 2014) papers, it was found differences between hematological and biochemical values. As it was refered, there are several factors that may influence thes results of these investigations, such as gender, age, genetic variation, diet and environmental conditions, so it is important the development of reference values.

\section{References}

ALMEIDA, A. S.; FALEIROS, A. C. G.; TEIXEIRA, D. N. S.; COTA, U. A.; CHICA, J. E. L. Reference values for bloodbased biochemical parameters in BALB/C and C57BL/6 wild-type mice. Jornal Brasileiro de Patologia e Medicina Laboratorial, v. 44, n. 6, p. 29-32, 2008. doi: http://dx.doi.org/10.1590/S1676-24442008000600006.

ANDERSEN, M. L.; D'ALMEIDA, V.; KO, G. M.; KAWAKAMI, R.; MARTINS, P. J. F. Princípios éticos e práticos do uso de animais de experimentação. São Paulo: Departamento de Psicobiologia. Escola Paulista de Medicina. Universidade Federal de São Paulo, 2004. 167 p.

ANDREOLLO, N. A.; SANTOS, E. F.; ARAÚJO, M. R.; LOPES, L. R. Rat's age versus human's age: what is the relationship? Arquivos Brasileiros de Cirurgia Digestiva, v. 25, n. 1, p. 49-51, 2012. doi: http://dx.doi.org/10.1590/S010267202012000100011 .

BRANCO, A. C. S. C.; DINIZ, M. F. F. M.; ALMEIDA, R. N.; SANTOS, H. B.; OLIVEIRA, K. M.; RAMALHO, J. A.; DANTAS, J. G. Biochemical and hematological parameters
Knowing that the Brazilian College of Animal Experimentation (CONCEA) requires the registration of research Laboratory Animal Facilities in Brazil, it is essential to have the largest number of data as possible from different strains of mice, so it will possible to establish more confident references.

\section{Conclusion}

The data presented in this study show a confidence range for hematological and biochemical parameters that are considered appropriate for mice used in scientific research.

\section{Acknowledgements}

This investigation was supported by grants from the Fundação de Amparo à Pesquisa do Estado de São Paulo (FAPESP), Conselho Nacional de Pesquisa (CNPq) and Coordenação de Aperfeiçoamento de Pessoal de Nível Superior (CAPES).

of wistar rats and Swiss mice in the Professor Thomas George Animal Laboratory. Revista Brasileira de Ciências da Saúde, v. 15, n. 2, p. 209-214, 2011. doi: http://dx.doi.org/10.4034/RBCS.2011.15.02.11.

CLINICAL AND LABORATORY STANDARDS INSTITUTE (CLSI). How to define and determine reference intervals in the clinical laboratory: approved guideline. Wayne, PA, USA: CLSI, 2000. (CLSI document C28-A2).

DACIE, J. V.; LEWIS, S. M. Practical haematology. $6^{\text {th }}$ ed. London: Churchill Livingstone, 1985. 516 p.

EMES, R. D.; GOODSTADT, L.; WINTER, E. E.; PONTING, C. P. Comparison of the genomes of human and mouse lays the foundation of genome zoology. Human Molecular Genetics, v. 12, n. 7, p. 701-709, 2003. doi: http://dx.doi.org/10.1093/hmg/ddg078.

FOSTER, H. L.; SMALL, J. D.; FOX, J. G. The mouse in biomedical research. New York, NY: Academic Press, 1982. $466 \mathrm{p}$. 
JACKSON LABORATORY. Physiological data summary: C57BL/6J (000664). 2007. Available from: <http://goo.gl/ifxEdR >. Viewed: 13 Jan. 2016.

MITRUKA, B. M.; RAWNSLEY, H. M. Clinical biochemical and hematological reference values in normal experimental animals. New York: Masson Publishing, 1997. 272 p.

NATIONAL RESEARCH COUNCIL.(NRC). Guide for care and use of laboratory animals. $8^{\text {th }}$ ed. Washington: The National Academies Press, 2011. 248 p.

NATIONAL RESEARCH COUNCIL (NRC). Nutrient requirements of laboratory animals. $4^{\text {th }}$ ed. rev. Washington: The National Academies Press, 1995. 192 p.

QUINN, R. Comparing rat's to human's age: how old is my rat in people years? Nutrition, v. 21, n. 6, p. 775-777, 2005.

REEVES, P. G.; NIELSEN, F. H.; FAHEY, G. C. AIN-93 purified diets for laboratory rodents: final report of the American Institute of Nutrition ad hoc writing committee on the reformulation of the AIN-76A rodent diet. The Journal of Nutrition, v. 123, n. 11, p. 1939-1951, 1993.

RESTELL, T. I.; PORFIRIO, L. C.; SOUZA, A. S.; SILVA, I. S. Hematology of Swiss mice (Mus musculus) of both genders and different ages. Acta Cir Bras. n. 5, p. 306-12. 2014.
RIVERA, E. A. B. Bem-estar na experimentação animal. In: FEIJÓ, A. G. S.; BRAGA, L. M. G. M.; PITREZ, P. M. C. Animais na pesquisa e no ensino: aspectos éticos e técnicos. Porto Alegre: EDIPUCRS, 2010. p. 74-88.

ROSENFELD, G. Método rápido de coloração de esfregaços de sangue: noções práticas sobre corantes pancrômicos e estudos de diversos fatores. Memórias do Instituto Butantan, v. 20, p. 315-328, 1947.

SERFILIPPI, L. M.; PALLMAN D. R.; RUSSELL, B. Serum clinical chemistry and hematology reference values in outbred stocks of albino mice from three commonly used vendors and two inbred strains of albino mice. Contemporary Topics in Laboratory Animal Science, v. 42, n. 3, p. 46-52. 2003.

TACONIC. Hematology. [200-]. Available from: <http://goo.gl/09mblJ>. Viewed: 13 Jan. 2016.

TEIXEIRA, M. A.; FILHO, A. F. L. Impacto dos fatores ambientais. In: LAPCHIK, V. B. V.; MATTARAIA, V. G. M.; KO, G. M. Cuidados e manejo de animais de laboratório. São Paulo: Atheneu, 2009. p. 101-111. 